The University of Southern Mississippi The Aquila Digital Community

Faculty Publications

$12-1-2002$

\title{
Interrelationships Among Landscapes, NDVI, and Stream Water Quality in the US Central Plains
}

Jerry A. Griffith

University of Southern Mississippi

Edward A. Martinko

University of Kansas

Jerry L. Whistler

University of Kansas

Kevin P. Price

University of Kansas

Follow this and additional works at: http://aquila.usm.edu/fac_pubs

Part of the Geography Commons

\section{Recommended Citation}

Griffith, J. A., Martinko, E. A., Whistler, J. L., Price, K. P. (2002). Interrelationships Among Landscapes, NDVI, and Stream Water Quality in the US Central Plains. Ecological Applications, 12(6), 1702-1718.

Available at: http://aquila.usm.edu/fac_pubs/3442

This Article is brought to you for free and open access by The Aquila Digital Community. It has been accepted for inclusion in Faculty Publications by an authorized administrator of The Aquila Digital Community. For more information, please contact Joshua.Cromwell@usm.edu. 


\title{
INTERRELATIONSHIPS AMONG LANDSCAPES, NDVI, AND STREAM WATER QUALITY IN THE U.S. CENTRAL PLAINS
}

\author{
Jerry A. Griffith, ${ }^{1.2 .3,6}$ Edward A. Martinko, ${ }^{1,3,4,5}$ Jerry L. Whistler, ${ }^{1.3}$ And Kevin P. Price ${ }^{1,2.3}$ \\ ${ }^{1}$ Kansas Applied Remote Sensing Program, University of Kansas, Lawrence, Kansas 66045 USA \\ 2Department of Geography, University of Kansas, Lawrence, Kansas 66045 USA \\ ${ }^{3}$ Kansas Biological Survev, University of Kansas, Lawrence, Kansas 66045 USA \\ ${ }^{4}$ Department of Ecology and Evolutionary Biology, University of Kansas, Lawrence, Kansas 66045 USA \\ ${ }^{5}$ Environmental Studies Program, University of Kansas, Lawrence, Kansas 66045 USA
}

\begin{abstract}
During late spring through summer of 1994 and 1995, 290 randomly selected stream sites in Nebraska, Kansas, and Missouri were sampled once for several parameters including conductivity, turbidity, total phosphorus, nitrate-nitrite nitrogen, the index of biotic integrity, and a habitat index. Based on landscape data from watersheds that were delineated for each sampling location, interrelationships were examined between these water quality parameters and land use/land cover, the normalized difference vegetation index (NDVI), and vegetation phenological metrics derived from the NDVI. Statistically significant relationships were found between NDVI values and the derived metrics with the stream condition parameters ( $r$ values to $0.8, \alpha=0.05$ ). The NDVI or vegetation phenological metrics (VPMs) were more highly correlated to the selected stream condition parameters than were the land use/land cover proportions. Knowledge of the general land use/land cover setting within the watersheds, however, was important for interpreting these relationships. The most common variables associated with the stream data were early spring NDVI values or VPMs associated with the date of onset of greenness. These results demonstrate the utility of NDVI and VPMs as broad-scale environmental indicators of watershed conditions.
\end{abstract}

Key words: ecological monttoring; Great Plains, USA; land use/land cover; NDVI; vegetation phenological metrics; water quality.

\section{INTRODUCTION}

Landscape properties such as riparian zone condition, channel slope and aspect, Quaternary and bedrock geology, vegetation, and hydrography all affect the structure and function of aquatic systems (Townsend et al. 1997). One of the most significant determinants of water quality, however, is land use/land cover (LULC). In particular, agricultural activities are among the most frequently cited sources for degradation and pollution of aquatic resources, primarily due to nutrient enrichment and sediment runoff (Cooper 1993). These impacts are of special interest in a predominantly agricultural region such as the Central Plains of Nebraska, Kansas, and Missouri. The conversion of native forest and riparian vegetation to agriculture, or of native grassland to pasture, has a profound influence on stream chemistry and also affects discharge, temperature, channel characteristics, bed disturbance regime, and energy and organic matter input (Townsend et al. 1997, Townsend and Riley 1999). These physical changes in turn impact stream biota (Richards et al.

Manuscript received 20 February 2001; revised 15 November 2001; accepted 17 February 2002; final version received 14 March 2002

${ }^{6}$ Present address: Department of Geography, University of Southern Mississippi, Box 5051, Hattiesburg, Mississippi 39406 USA.
1996, Wichert and Rapport 1998). Reviews of the general impacts of agriculture on instream sediments, nutrients, organic contamination and pesticides/metals can be found in Cooper (1993), Matson et al. (1997), and Skinner (1997).

The relationship between LULC and water quality has long been studied (Omernik 1976, Osborne and Wiley 1988, Lenat and Crawford 1994, Roth et al. 1996, Allan et al. 1997, Johnson et al. 1997, Basnyat et al. 1999). Johnson et al. (1997) provide a summary of studies that examine the impact of LULC on water quality. In particular, strong relationships have been found between LULC and phosphorus and nitrogen (Peterjohn and Correll 1984, Lowrance et al. 1985, Keeney and DeLuca 1993, Hall and Schreier 1996, Bolstad and Swank 1997). The importance of these interrelationships is reflected by the increased recognition since the 1980s of nonpoint-source pollution as a major environmental concern (Sharpley and Meyer 1994, Loague 1998).

To address water quality degradation from agricultural nonpoint-source pollution and other impacts, management perspectives are shifting away from the analysis of stream reaches only to a broader landscape perspective (Sidle and Hornbeck 1991, Johnson and Gage 1997, O’Neill et al. 1997, Wiley et al. 1997). Consensus is forming that analyses of stream condition must include both small-scale (stream reaches) and 
large-scale (whole catchments) landscape studies (Schlosser 1991, Johnson and Gage 1997, Johnson et al. 1997). Landscape-level analysis allows quicker assessment of problems and a cost-effective way to focus protection and restoration efforts. As a result, regional land use and land cover information is increasingly used to support water quality studies (Zelt et al. 1995).

Advances in remote sensing and GIS technologies have made regional and landscape-level studies and management strategies much more feasible (Johnson and Gage 1997). Consequently, the future trend is for more frequent use of remotely sensed data and GIS as they become increasingly available through various federal programs. One management tool borne from a landscape perspective and commonly employed in aquatic resource studies are ecoregions (Omernik 1995, 1987). Ecoregions are used to stratify areas based on similar environmental váriables for research and resource management purposes. Using ecoregions as a basis for management decisions is beneficial because ecoregions integrate multiple factors (e.g., physiography, vegetation, land use, geology, and soils) that determine the character and quality of terrestrial and aquatic natural resources (Omernik 1995, Bryce et al. 1999).

Stream biological communities and physical habitat are also affected by agricultural and other land uses (Roth et al. 1996). For example, fish communities in Kansas and the Central Plains area have been impacted by habitat alteration and degradation (Cross and Collins 1995). In larger streams, such changes include channel narrowing and flow modifications from dams that have stabilized previously variable hydrologic regimes to which Great Plains fish communities had adapted (Cross et al. 1986, Eberle et al. 1993, Cross and Collins 1995). In smaller streams as well, many problems arise from agricultural impacts. These include siltation of previously clear streams and dewatering of streams from both intensive groundwater mining for irrigation and conservation practices such as farm ponds and conservation tillage (Cross and Collins 1995).

Smith et al. (2000) discussed the development of environmental indicators of agroecosystems to estimate their environmental trends, conditions, and sustainability. Analysis of biotic resources is important as aquatic resource managers focus increased attention on biological indicators of stream condition as opposed to physicochemical parameters (Karr 1991, 1993, Roux et al. 1993). One reason for this is that fish communities are considered integrators of watershed condition (Wichert and Rapport 1998), and thus they indirectly reflect agroecosystem condition. A commonly used biological assessment tool is the index of biotic integrity (IBI; Karr et al. 1986, Karr and Chu 1997). The IBI evaluates biotic variables in a stream relative to a similar-sized stream in the same region where human disturbance has been minimal. This technique allows comparative evaluation of metrics based on abundance, spe- cies richness, condition, presence of alien species, and representation of relevant trophic and habitat guilds (Harris and Silveira 1999). Multimetric habitat indices are also frequently used to characterize and evaluate stream conditions (Kaufmann et al. 1999, Maddock 1999).

Most of the aforementioned studies that relate LULC to water quality or stream biological/habitat conditions have employed traditional land cover maps. This type of land cover characterization is temporally static, however, and does not account for seasonal (phenological), interannual, or directional (successional/human induced) changes (Hobbs 1990). A different approach to relating gross vegetation types (i.e., land cover) to water quality and stream conditions is through the use of the normalized difference vegetation index (NDVI) values derived from satellite or airborne sensors. The NDVI is widely used, has become a standard for band ratio applications, and has a long history of use in remote sensing, ecology, and geography to study characteristics of vegetation, including amount (biomass), type, and condition (Lauver and Whistler 1993, Jensen 1996). The NDVI is a reflection of biophysical conditions of a watershed's vegetation cover, which in turn affects water runoff and quality. One can approach in different ways the linkages among land cover, plant physiology, and water quality. One view is that NDVI is indicative of land cover and land use, but shows the biophysical condition of watersheds as well. Increased greenness (higher NDVI) at a certain time of the year may simply be indicative of a more intensively agricultural watershed, or may be indicative of increased fertilizer or chemical applications. This connection of NDVI providing an indication of the land cover classification along with intensity of agriculture is the approach that best fit our analysis of watersheds across a large spatial entity.

Whistler (1996) explored NDVI values derived from Landsat Multi-Spectral Scanner (MSS) imagery as a surrogate for biomass and hypothesized that they would have stronger relationships with water chemistry parameters than land cover proportions derived from the same imagery. He found significant relationships between NDVI and selected water quality parameters that in fact were stronger than relationships to LULC in many cases. In addition to the NDVI values, a suite of metrics describing vegetation phenology can be derived from NDVI time-series data (Reed et al. 1994). Some of these vegetation phenological metrics (hereafter referred to as VPMs) served as useful ancillary data in land cover classification of the conterminous U.S. (Loveland et al. 1995). The metrics have yet to be fully explored, however, for their potential application to the monitoring and assessment of water quality and stream conditions.

This study assesses NDVI and VPMs for environmental monitoring purposes in Nebraska, Kansas, and Missouri by examining their relationships with selected 
TABLE 1. Component indices or variables for the index of biotic integrity (IBI) and the habitat index (HI).

\begin{tabular}{cl}
\hline \hline \multicolumn{1}{c}{ Index } & \multicolumn{1}{c}{ Components } \\
\hline Index of biotic integrity & total number of fish species \\
& number and identity of darter species \\
& number and identity of sunfish species \\
& number and identity of sucker species \\
& number and identity of intolerant species \\
& proportion of individuals as green sunfish, carp, \\
& bullheads, goldfish \\
& proportion of individuals as omnivores \\
& proportion of individuals as insectivorous cyprinids \\
& proportion of individuals as piscivores (top carnivores) \\
& number of individuals in sample \\
& proportion of individuals with anomalies \\
& riparian vegetation quality \\
& lack of riparian human disturbance \\
Habstrate quality & in-channel disturbance and deviance from expected \\
channel morphology and substrate & habitat volume \\
& spatial complexity \\
instream fish cover \\
stream power and velocity
\end{tabular}

water quality parameters, the IBI, a habitat index (HI), and LULC. Specifically, the questions addressed are:

1) What are the relationships between NDVI and the selected water quality and stream condition measures? What are the relationships between the VPMs and selected water quality and stream condition parameters?

2) What are the relationships between LULC and water quality or stream condition?

3) How do LULC relationships with water quality compare with that of NDVI and VPMs to the selected water quality and stream condition parameters?

\section{Materials and Methods}

\section{The study area}

Although commonly perceived as homogenous, the landscapes of Nebraska, Kansas, and Missouri are surprisingly varied. Geology in the area consists of limestones and shales in central and eastern Kansas originating from shallow Paleozoic seas. The Nebraskan and Kansan glaciations deposited glacial drift across northern Missouri, eastern Nebraska, and northeastern Kansas. The Precambrian strata of the Ozark Uplands remained a nonglaciated area with steeper and more rugged terrain. Loess soils cover much of Nebraska, while stream sediments from the Rocky Mountains cover the western edges of Kansas and Nebraska (Williams and Murfield 1977). Precipitation ranges from 38-45 cm in westernmost Kansas and Nebraska to $90-100 \mathrm{~cm}$ in eastern Kansas, to nearly $120 \mathrm{~cm}$ on the Mississippi River in southeastern Missouri (Schroeder 1982, Goodin 1995). Native vegetation consisted of shortgrass prairie in westernmost Kansas and Nebraska, tallgrass and mixed-grass prairie in the Nebraska Sand Hills and central Kansas, a mosaic of bluestem prairie and oak- hickory forest in eastern Kansas and northern Missouri, and dense oak-hickory forests in the Ozark Highlands. The central human transformation of the Great Plains has been conversion of grassland to cropland. Currently, $90 \%$ of the area is in farms or ranches and $75 \%$ of the land is in cultivation (Riebsame 1990). Hydrological impacts stem from tillage, cropping, runoff change, water impoundment, groundwater depletion, and changes in soil structure and chemistry. Chapman et al. (2001) provide a physical geography synopsis of Kansas and Nebraska.

\section{Field data}

Water quality and stream condition data were collected by the U.S. Environmental Protection Agency (EPA) Region VII during the late spring and summer of either 1994 or 1995 (streams were sampled once) as part of its Regional Environmental Monitoring and Assessment Program (REMAP). Two hundred ninety stream sites were randomly selected in Kansas, Nebraska, and Missouri to assess fisheries health and stream condition, as well as to establish baseline data and methods usable for assessing long-term trends throughout the region (EPA 1997). Of the more than 30 water quality parameters examined, four water quality parameters that are important determinants of water quality and which integrate across the entire watershed were selected for this analysis: total phosphorus (TP), nitrate-nitrite nitrogen $\left(\mathrm{NO}_{2}-\mathrm{NO}_{3}\right)$, turbidity, and conductivity. In addition, the IBI and a habitat index (HI) were examined (Table 1). Analytical techniques used to determine the values for the water quality parameters and methods for calculating the IBI and HI are detailed in EPA (1997). 


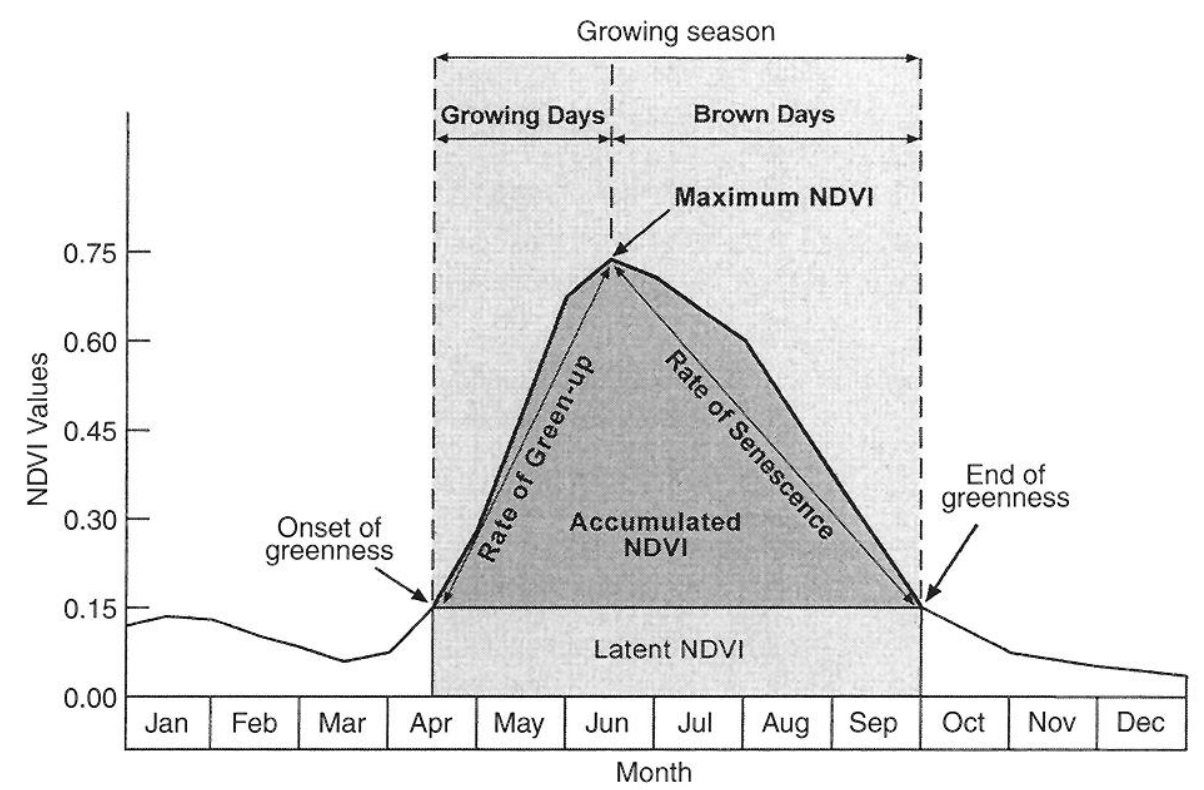

FIG. 1. Vegetation phenology curve and metrics derived from enhanced AVHRR imagery. This diagram of a 12-mo NDVI temporal response is for vegetation typical of the Great Plains. Greenness metrics that characterize vegetation phenology are illustrated on the curve to show the relationship between NDVI and time (after Reed et al. 1994). Table 2 shows examples of the NDVI-derived metrics, along with a brief description. Mean and standard deviation values were calculated for these derived VPMs. Higher NDVI values correlate with increased green, leafy biomass.

\section{Landscape data}

For each stream sampling point, contributing watershed areas were delineated and digitized. In some cases, only portions of watersheds were delineated; they were completed by merging the digitized portions with digital hydrologic unit (HUCs) boundary files of U.S. Department of Agriculture Natural Resources Conservation Service. Land cover data for the region were obtained from 1:250 000 U.S. Geological Survey (USGS) land use and land cover composite theme grid data (USGS 1990), which was processed from aerial photography from the middle and late 1970 s with a spatial resolution of $200 \mathrm{~m}$. Although the USGS data set is dated and has coarser resolution than other data sets derived from Landsat TM or MSS, preliminary analyses were done in Kansas on a 30-m TM-derived land cover map circa 1990 (Whistler et al. 1995). Results were mixed; for some variables the correlations were stronger and for others they were weaker. Usually, the magnitude of differences in correlation strength was not great. Moreover, Herlihy et al. (1998) found no major differences in LULC-stream water chemistry relationships when using either the USGS data set or the recently completed 30-m National Land Cover Data Set (NLCD). This result may be partly explained because the NLCD was meant for use with larger study units than small watersheds, on which any misclassification errors can have a relatively greater impact. The NLCD was not available at the start of this project; moreover, this data set was specifically intended for regional- and national-scale purposes (Vogelmann et al. 2001). Nev- ertheless, we acknowledge that exploring this data set may be useful in future studies, but at the start of this project, we felt the USGS LULC data was the best available data set that was consistently produced over our three-state study area.

NDVI and VPMs were derived from the National Oceanic and Atmospheric Administration's (NOAA) advanced very high resolution radiometer (AVHRR) satellite sensor. From the USGS conterminous U.S. biweekly composite database, 26 periods of biweekly NDVI composites for 1995 were used. Each composite is composed of the maximum NDVI value for every 1 $\times 1 \mathrm{~km}$ pixel over a 2-wk period (Eidenshink 1992). Roughly correlated to photosynthetic biomass, the NDVI is a ratio of near-infrared (NIR) and red solar energy reflectance values that is calculated as follows:

$$
\mathrm{NDVI}=\mathrm{NIR}-\mathrm{red} / \mathrm{NIR}+\mathrm{red} .
$$

In addition to the raw NDVI values, a series of derived metrics describing vegetation phenology were developed using algorithms modified from Reed et al. (1994). Fig. 1 and Table 2 show the basis for their calculation and Table 3 lists the specific dates of the biweekly composites used in this study. Loveland et al. (1995) used these VPMs to help classify LULC in the conterminous U.S. For each watershed, GIS overlays were used to extract LULC proportions and to calculate mean NDVI and VPM values for each biweekly period, as well as standard deviations of the VPMs. The $U$ index (human use index), which equals the proportions of agricultural plus urban lands, was 
TABLE 2. A serıes of satellite-derived metrics describing vegetation phenology.

\begin{tabular}{|c|c|}
\hline Metric name & Parameter being measured \\
\hline \multicolumn{2}{|l|}{ Temporal metrics } \\
\hline Date of onset of greenness $\dagger$ & beginning of photosynthetic activity \\
\hline Date of end of greenness & end of photosynthetic activity \\
\hline Duration of greenness & length of photosynthetic activity \\
\hline Date of maximum greennesst & time when photosynthesis is at maximum \\
\hline Growing days $\dagger$ & number of days from onset of greenness to maximum NDVI \\
\hline Growing season $\dagger$ & number of days from onset of greenness to end of greenness \\
\hline \multicolumn{2}{|l|}{ NDVI-value metrics } \\
\hline Value of onset of greenness $\dagger$ & level of photosynthesis at start \\
\hline Value of end of greenness & level of photosynthesis at end \\
\hline Value of maximum NDVI $\dagger$ & level of photosynthesis at maximum \\
\hline Range of NDVI & range of measurable photosynthesis \\
\hline \multicolumn{2}{|l|}{ Derived metrics } \\
\hline Accumulated NDVI & net primary production \\
\hline Rate of green up $\dagger$ & acceleration of increasing photosynthesis \\
\hline Rate of senescence & acceleration of decreasing photosynthesis \\
\hline Mean daily NDVI & mean darly photosynthesis activity \\
\hline
\end{tabular}

Note: These calculations were developed usıng algorithms modified from Reed et al. (1994).

$\dagger$ Metrics used in the analysis.

also calculated and has been used to gauge the level of total anthropogenic disturbance in regional landscapes (EPA 1994).

The data were geographically stratified using ecoregions used by the EPA (Omernik 1987) (Fig. 2). Only watersheds with at least two-thirds of their area in one ecoregion were used. The exception to this was for two ecoregions adjacent to the Mississippi River that were combined (the Interior River Lowlands and Mississippi Alluvial Plains), because there were so few watersheds that were fully contained in them even after they were combined. The Western High Plains, Southwestern Tablelands, and Northwestern Great Plains were also grouped into one region to increase the watershed sample size. If there were a large enough number of samples in any one ecoregion, watershed area was used for stratification. These divisions were made by examining histograms of watershed area and choosing logical break points, while also maintaining adequate sample size.

Pearson product-moment correlation analysis (Stevens 1996) was used to investigate relationships between the stream field data and the LULC, the NDVI, and the VPMs. The water quality data and LULC data were $\log$ or square-root transformed to normalize the data. Normality of the NDVI and VPMs for each ecoregion was checked before correlation analysis. If severe deviation from normality occurred for a variable, that variable was not reported in the results. Because the sampling points were randomly chosen, watershed area ranged widely and was included in the correlation analyses. For instances where watershed area was significantly correlated with a stream variable, partial correlation analysis was performed to control for watershed area. Although multiple correlations were made, we decided to maintain the standard alpha level of 0.05 , because we were treading new ground in studying these variables and did not want to dismiss any potential relationships. Moreover, previous work done with aggregations of ecoregions, and thus fewer comparisons, had similar results (Griffith et al. 2000).

\section{RESULTS}

The spatial distribution of the watersheds is shown in Fig. 3, and Table 4 lists watershed sizes for each ecoregion. In cases where partial correlation was performed to control for a significant relationship between watershed area and a stream variable, there still existed in every case a significant relationship between the variables in question. For purposes of consistency, only the Pearson product-moment correlation coefficients are reported. Table 5 lists the correlation coefficients for relationships between the stream parameters and

TABle 3. Calendar dates for the biweekly NDVI composites.

\begin{tabular}{lc}
\hline \hline NDVI values & $\begin{array}{c}1995 \text { biweekly } \\
\text { composites }\end{array}$ \\
\hline Period 7 & $31 \mathrm{Mar}-14 \mathrm{Apr}$ \\
Period 8 & $15 \mathrm{Apr}-27 \mathrm{Apr}$ \\
Period 10 & $12 \mathrm{May}-25 \mathrm{May}$ \\
Period 11 & $26 \mathrm{May}-8 \mathrm{Jun}$ \\
Period 12 & $9 \mathrm{Jun}-22 \mathrm{Jun}$ \\
Period 13 & $23 \mathrm{Jun}-6 \mathrm{Jul}$ \\
Period 14 & $7 \mathrm{Jul}-20 \mathrm{Jul}$ \\
Period 15 & $21 \mathrm{Jul}-3 \mathrm{Aug}$ \\
Period 16 & 4 Aug-17 Aug \\
Period 17 & 18 Aug-31 Aug \\
Period 18 & $1 \mathrm{Sep}-14 \mathrm{Sep}$ \\
Period 19 & $15 \mathrm{Sep}-28 \mathrm{Sep}$ \\
Period 20 & $29 \mathrm{Sep}-12 \mathrm{Oct}$ \\
Period 21 & $13 \mathrm{Oct}-26 \mathrm{Oct}$ \\
Period 22 & 27 Oct-9 Nov \\
\hline
\end{tabular}

Note: Period 9 had significant cloud cover remaining in the composite and was not used in the analysis. 


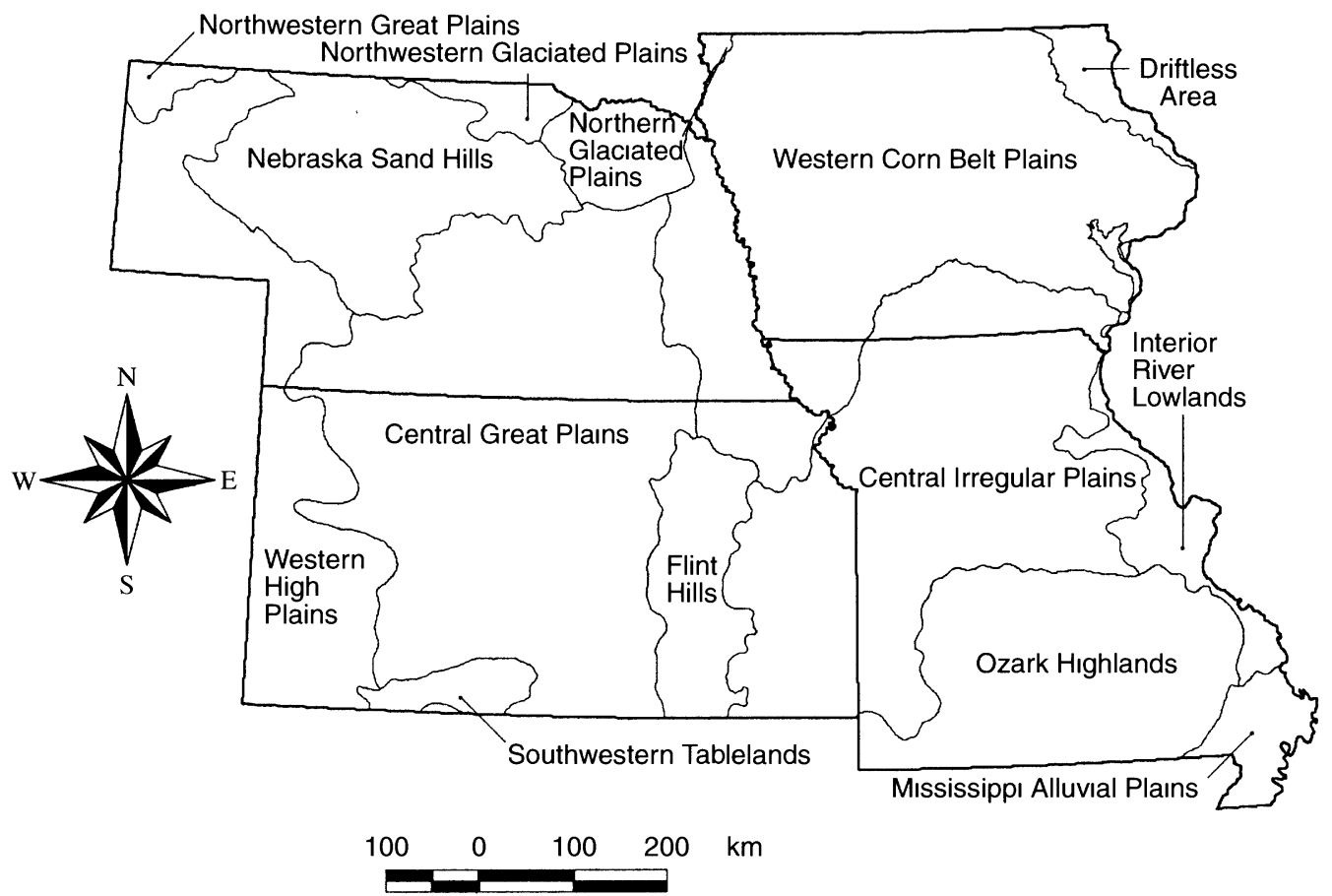

FIG. 2. Ecoregions of EPA Region VII (Nebraska, Kansas, Missouri, and Iowa; from Omernik [1987]). Note that no water quality data were collected for Iowa.

the NDVI/VPM values for selected ecoregions where correlations were the strongest (generally $r>0.4$ ).

Table 6 lists the $r$ values showing the correlations for selected ecoregions that were also stratified by watershed area. An analysis of the full list of all statistically significant correlations at $\alpha=0.05$ (not shown) revealed that the variables having the greatest number of significant correlations with the stream field parameters were NDVI values for periods 8, 10, 11 (April through late May), mean date of onset of greenness (late March through late May), and the standard deviation of NDVI values at the onset of greenness. These variables also had the greatest number of strong correlations (considered here to be $r \geq 0.65$; that is, explaining $\geq 40 \%$ of the variation in a stream parameter). In each ecoregion there were usually only one or two variables for which correlations were $\geq 0.65$. The Mississippi River Lowlands and Central Irregular Plains (watersheds $>260 \mathrm{~km}^{2}$ ) had the greatest number of correlations with $r \geq 0.65$, although most of these were

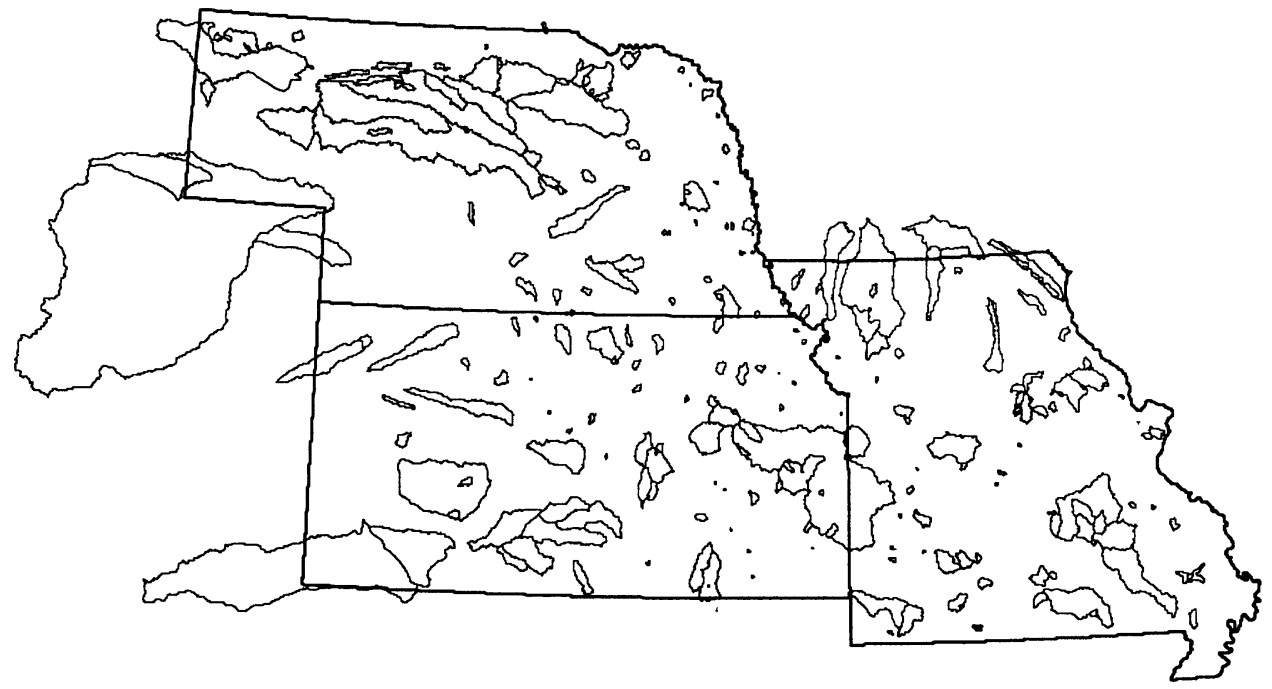

FIG. 3. The watersheds for the streams sampled in Region VII of the Environmental Protection Agency. 
TABLE 4. Mean and range of watershed sizes $\left(\mathrm{km}^{2}\right)$ in each ecoregion.

\begin{tabular}{lrrr}
\hline \hline \multicolumn{1}{c}{ Mean } & & \\
Eater- & $\begin{array}{c}\text { Ehed } \\
\text { area }\end{array}$ & $\begin{array}{c}\text { Mini- } \\
\text { mum }\end{array}$ & $\begin{array}{c}\text { Maxi- } \\
\text { mum }\end{array}$ \\
\hline Western plains and tablelands & 1831 & 10.1 & 17415 \\
Flint Hills & 228 & 0.5 & 1067 \\
Sand Hills & 2212 & 9.6 & 13499 \\
Western corn belt plains & 126 & 1.6 & 1836 \\
Central irregular plains & 571 & 2.3 & 14688 \\
Ozark highlands & 452 & 3.6 & 3929 \\
Central Great Plains & 587 & 3.9 & 5970 \\
Mississippi River lowlands & 379 & 2.8 & 3447 \\
\hline
\end{tabular}

for one stream parameter only, such as the IBI or HI. With respect to water chemistry, conductivity and $\mathrm{NO}_{2}-\mathrm{NO}_{3}$ had the greatest number of strong correlations with the NDVI or VPMs. Most of the stronger relationships were associated with one ecoregion, such as the Sand Hills for conductivity and the Western Corn Belt Plains (watersheds $>25 \mathrm{~km}^{2}$ ) for $\mathrm{NO}_{2}-\mathrm{NO}_{3}$. Total phosphorus had the least number of strong correlations with the NDVI/VPMs.

In ecoregions stratified by size, correlations were slightly higher for the larger watersheds in the Western Corn Belt Plains and Central Irregular Plains (Table 6). For the Ozark Highlands and Central Great Plains, no definite trend was observed. Different watershed size groups in these ecoregions each had a stream variable for which correlation with an NDVI/VPM was greater than in the other watershed size groups. Generalizing the results from Tables 5 and 6, NDVI in the early growing season seemed to be most often correlated with water quality. This general category includes NDVI values from Periods 8-11 (late April to midJune) and mean NDVI at the onset of greenness, date of onset of greenness, or standard deviation of these values. Peak growing season NDVI metrics, such as NDVI from periods 12 through 18 (late June to late September), or maximum NDVI, date of maximum NDVI, or the standard deviation of these values were also frequently correlated with IBI and the HI. Figs. 4 and 5 show scatterplots of the strongest correlations.

To help interpret these results, it was useful to examine correlations between the NDVI, VPMs, and land cover (Table 7), and LULC proportions for the selected ecoregions (Fig. 6). In addition, we identified relatively pure areas of known LULC and verified the phenologies as described herein. Because the streams were only sampled once in late spring or summer, and not at biweekly intervals concurrent with the NDVI data, it is important to view these relationships (especially regarding the nutrients) as revealing the general effects of agriculture. This situation might contrast with that of a year's profile of both water quality and NDVI data wherein one might expect to observe higher nutrients in winter, when actively growing vegetation is not pres-
TABLE 5. Pearson correlation coefficients (significant at $\alpha$ $=0.05)$ in selected ecoregions.

\begin{tabular}{|c|c|c|c|}
\hline Variable & Correlated variable & $r$ & $n$ \\
\hline \multicolumn{4}{|c|}{ A) Western plains and tablelands $\dagger$} \\
\hline \multirow[t]{3}{*}{ Conductıvity } & $\mathrm{AG}$ & 0.46 & 24 \\
\hline & onset NDVI SD & 0.65 & 24 \\
\hline & date of maximum NDVI SD & 0.57 & 24 \\
\hline \multirow[t]{2}{*}{ Turbidity } & $\log ($ URB $)$ & 0.50 & 21 \\
\hline & P22 NDVI & 0.57 & 21 \\
\hline \multirow[t]{4}{*}{$\mathrm{TP}$} & $\mathrm{AG}$ & 0.71 & 25 \\
\hline & $U$ index & 0.73 & 25 \\
\hline & mean onset date & -0.74 & 25 \\
\hline & P8 NDVI & 0.71 & 25 \\
\hline HI & date of maximum NDVI & 0.47 & 25 \\
\hline \multicolumn{4}{|l|}{ B) Flint Hills } \\
\hline \multirow[t]{3}{*}{ Turbidity } & FOR & 0.48 & 19 \\
\hline & mean onset date & -0.76 & 19 \\
\hline & P18 NDVI & -0.70 & 19 \\
\hline \multirow[t]{2}{*}{$\mathrm{NO}_{2}-\mathrm{NO}_{3}$} & mean onset date SD & 0.65 & 21 \\
\hline & onset $\mathrm{N}$ & 0.53 & \\
\hline \multicolumn{4}{|l|}{ C) Sand Hills } \\
\hline \multirow[t]{3}{*}{ Conductivity } & GRA & -0.59 & 19 \\
\hline & mean onset NDVI & 0.70 & 19 \\
\hline & P14 NDVI & 0.69 & 19 \\
\hline \multirow[t]{2}{*}{$\mathrm{NO}_{2}-\mathrm{NO}_{3}$} & mean growth rate & -0.48 & 20 \\
\hline & mean no. growing days & 0.47 & 20 \\
\hline \multirow[t]{3}{*}{$\mathrm{TP}$} & $\log (A G)$ & 0.54 & 20 \\
\hline & Pl1 NDVI & 0.57 & 20 \\
\hline & P8 NDVI & 0.53 & 20 \\
\hline \multicolumn{4}{|c|}{ D) Western Corn Belt } \\
\hline \multirow[t]{3}{*}{ Conductivity } & GRA & -0.59 & 33 \\
\hline & P22 NDVI & 0.41 & 33 \\
\hline & P11 NDVI & 0.35 & 33 \\
\hline \multirow[t]{4}{*}{ Turbidity } & $\log (\mathrm{FOR})$ & 0.54 & 29 \\
\hline & $\log (A G)$ & -0.47 & 29 \\
\hline & $U$ index & -0.50 & 29 \\
\hline & P14 NDVI & 0.49 & 29 \\
\hline \multirow[t]{2}{*}{$\mathrm{NO}_{2}-\mathrm{NO}_{3}$} & P10 NDVI & -0.69 & 34 \\
\hline & P8 NDVI & -0.66 & 34 \\
\hline TP & $U$ index & -0.50 & 34 \\
\hline \multirow[t]{2}{*}{ IBI } & mean growth rate & -0.65 & 34 \\
\hline & P15 NDVI & -0.64 & 34 \\
\hline \multirow[t]{2}{*}{ HI } & mean onset date & -0.49 & 34 \\
\hline & P10 NDVI & 0.48 & 34 \\
\hline \multicolumn{4}{|c|}{ E) Mississippi Valley lowlands $\ddagger$} \\
\hline Conductivity & Onset NDVI SD & -0.72 & 9 \\
\hline \multirow{2}{*}{ Turbidity } & P18 NDVI & -0.78 & 10 \\
\hline & date of maximum NDVI & -0.66 & 10 \\
\hline \multirow{3}{*}{$\begin{array}{l}\mathrm{NO}_{2}-\mathrm{NO}_{3} \\
\mathrm{TP}\end{array}$} & mean no. growing days & -0.62 & 11 \\
\hline & FOR & -0.69 & 11 \\
\hline & $U$ index & 0.71 & 11 \\
\hline & onset NDVI SD & -0.70 & 11 \\
\hline IBI & $\log (\mathrm{URB})$ & -0.73 & 11 \\
\hline & P18 NDVI & 0.79 & 11 \\
\hline & P16 NDVI & 0.78 & 11 \\
\hline & date of maximum NDVI SD & 0.76 & 11 \\
\hline
\end{tabular}

Notes: Listed are the two most strongly correlated NDVI values or vegetation phenologic metrics (VPMs). If a LULC type was significantly correlated to a water-quality or streamcondition variable, it was listed; if none is shown, there were no LULC types significantly correlated at $\alpha=0.05$. In general, NDVI and VPMs were as highly correlated to water quality as LULC. In many cases, while an NDVI or VPM was significantly correlated to a stream variable, an LULC type was not. Abbreviations are: TP, total phosphorus; IBI, index of biotic integrity; $\mathrm{HI}$, habitat index; $\mathrm{AG}$, percentage of land in agriculture; URB, percentage of land that is urban; $U$ index, human use index; $\mathrm{P}$ followed by a number is the period number; FOR, percentage of land in forest; GRA, percentage of land in grass.

† Consists of the western high plains, northwestern Great Plains, and southwestern tablelands ecoregions.

\$Consists of the interior river lowlands and Mississippi alluvial plains ecoregions. 
TABLE 6. Pearson correlation coefficients (significant at $\alpha=$ 0.05 ) in selected ecoregions, which are also stratified by watershed size.

\begin{tabular}{|c|c|c|c|}
\hline Variable & Correlated variable & $r$ & $n$ \\
\hline \multicolumn{4}{|c|}{ A) Western corn belt $>10 \mathrm{mi}^{2}\left(25 \mathrm{~km}^{2}\right)$} \\
\hline Conductivity & P20 NDVI & 0.54 & 16 \\
\hline \multirow[t]{2}{*}{$\mathrm{NO}_{2}-\mathrm{NO}_{3}$} & $\begin{array}{l}\text { mean onset date } \\
\text { P10 NDVI }\end{array}$ & $\begin{array}{r}0.75 \\
-0.73\end{array}$ & $\begin{array}{l}17 \\
17\end{array}$ \\
\hline & mean growth rate & 0.71 & \\
\hline TP & $\log (\mathrm{URB})$ & 0.48 & 17 \\
\hline \multirow[t]{2}{*}{ IBI } & P15 NDVI & -0.66 & 17 \\
\hline & maximum NDVI & -0.61 & \\
\hline \multirow{3}{*}{$\mathrm{HI}$} & $\log (A G)$ & 0.60 & 17 \\
\hline & $U$ index & 0.65 & \\
\hline & mean onset date & -0.55 & \\
\hline \multicolumn{4}{|c|}{ B) Central irregular plains $>100 \mathrm{mi}^{2}\left(260 \mathrm{~km}^{2}\right)$} \\
\hline \multirow{2}{*}{ Conductivity } & mean no. growing days & 0.60 & 18 \\
\hline & $\begin{array}{l}\text { P19 NDVI } \\
\text { onset NDVI SD }\end{array}$ & $\begin{array}{r}0.68 \\
-0.87\end{array}$ & \\
\hline \multirow{2}{*}{ Turbidity } & P8 NDVI & -0.73 & 15 \\
\hline & mean onset date SD & -0.79 & 15 \\
\hline \multirow{4}{*}{$\begin{array}{l}\mathrm{NO}_{2}-\mathrm{NO}_{3} \\
\mathrm{IBI}\end{array}$} & P20 NDVI & -0.52 & 15 \\
\hline & onset date SD & 0.64 & 18 \\
\hline & onset ND & 0.5 & \\
\hline & P14 ND & -0.57 & 18 \\
\hline \multirow[t]{3}{*}{$\mathrm{HI}$} & onset da & 0.71 & 17 \\
\hline & $\mathrm{P} 14 \mathrm{NI}$ & -0.70 & \\
\hline & onset NDVI SD & 0.68 & \\
\hline \multicolumn{4}{|c|}{ C) Ozarks $<20 \mathrm{mi}^{2}\left(50 \mathrm{~km}^{2}\right)$} \\
\hline \multirow{5}{*}{$\begin{array}{l}\text { Conductivity } \\
\text { Turbidity } \\
\mathrm{NO}_{2}-\mathrm{NO}_{3} \\
\mathrm{TP}\end{array}$} & P9 NDVI & -0.55 & 14 \\
\hline & $\log (\mathrm{AG})$ & 0. & 15 \\
\hline & P18 NDVI & -0.52 & 15 \\
\hline & P8 NDVI & -0.5 & 15 \\
\hline & onset date & 0. & 15 \\
\hline \multirow[t]{2}{*}{ IBI } & NDVI SD & 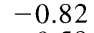 & 14 \\
\hline & P8 NDVI & -0 & 14 \\
\hline \multirow[t]{3}{*}{ HI } & $\log (\mathrm{AG})$ & -0.64 & 15 \\
\hline & & & \\
\hline & mean no. growing days & -0.59 & \\
\hline \multicolumn{4}{|c|}{ D) Ozarks $>100 \mathrm{mi}^{2}\left(260 \mathrm{~km}^{2}\right)$} \\
\hline $\mathrm{NO}_{2}-\mathrm{NO}_{3}$ & $\begin{array}{l}\text { date of maximum NDVI SD } \\
\text { P13 NDVI }\end{array}$ & $\begin{array}{r}0.77 \\
-0.67\end{array}$ & $\begin{array}{l}10 \\
10\end{array}$ \\
\hline \multicolumn{4}{|c|}{ E) Central Great Plains $<30 \mathrm{mi}^{2}\left(75 \mathrm{~km}^{2}\right)$} \\
\hline $\mathrm{NO}_{2}-\mathrm{NO}_{3}$ & $\begin{array}{l}\text { P14 NDVI } \\
\text { P18 NDVI }\end{array}$ & $\begin{array}{l}0.60 \\
0.55\end{array}$ & $\begin{array}{l}20 \\
20\end{array}$ \\
\hline \multirow[t]{2}{*}{$\mathrm{TP}$} & date of maximum NDVI SD & 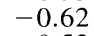 & 20 \\
\hline & & -0.52 & 20 \\
\hline \multirow[t]{2}{*}{ HI } & date of maximum NDVI SD & 0.60 & 20 \\
\hline & & & \\
\hline \multicolumn{4}{|c|}{ F) Central Great Plains $>100 \mathrm{mi}^{2}\left(260 \mathrm{~km}^{2}\right)$} \\
\hline \multirow[t]{2}{*}{ Conductivity } & $\log ($ GRA $)$ & 0.49 & 18 \\
\hline & & & \\
\hline \multirow{3}{*}{ TP } & set date & & 18 \\
\hline & date of maximum NDVI SD & -0.77 & \\
\hline & onset NDVI SD & -0.63 & 18 \\
\hline IBI & mean onset NDVI SD & 0.65 & 19 \\
\hline & mean onset NDVI & & 19 \\
\hline HI & $\begin{array}{l}\log (\text { URB }) \\
\text { onset NDVI SD }\end{array}$ & $\begin{array}{r}-0.51 \\
0.54\end{array}$ & $\begin{array}{l}19 \\
19\end{array}$ \\
\hline
\end{tabular}

Notes: Listed are the two most strongly correlated NDVI values or vegetation phenologic metrics (VPMs). If a LULC type was significantly correlated to a water quality or stream condition variable, it was listed; if none is shown, there were no LULC types significantly correlated at $\alpha=0.05$. In general, NDVI and VPMs were as highly correlated to water quality as LULC. In many cases, while an NDVI or VPM was significantly correlated to a stream variable, an LULC type was not. Abbreviations are: TP, total phosphorus; IBI, index of biotic integrity; HI, habitat index; $A G$, percentage of land in agriculture; URB, percentage of land that is urban; $U$ index, human-use index; $\mathrm{P}$ followed by a number is the period number; FOR, percentage of land in forest; GRA, percentage of land in grass. ent (lower NDVI) for nutrient uptake, versus lower concentrations of nutrients in the growing season (higher NDVI) when vegetation is actively taking up nutrients.

\section{Discussion}

Key points emerging from these results are:

1) The NDVI or VPMs were, in most cases, correlated with the stream field data as highly or more strongly than simple land-cover proportions. In many cases, land-cover proportions were not significantly correlated with the stream data, while an NDVI date or VPM value was.

2) An NDVI date or VPM was often correlated with LULC, and this relationship in turn helped explain relationships between an NDVI or VPM and the stream field data.

3) The context of LULC within a region as well as general regional crop types are important when interpreting NDVI/VPM relationships with the stream data.

In the majority of cases, the NDVI or VPMs performed better than simple land cover proportions in explaining variation in water quality parameters ( $\mathrm{Ta}$ bles 5,6$)$. In fact, for over one-half of the instances where an NDVI or VPM was significantly correlated with any of the stream variables, an LULC type was not significantly correlated. This increased performance of the AVHRR-derived metrics relative to LULC was evident even though the AVHRR data have a spatial resolution of $1 \mathrm{~km}$ compared to the $200-\mathrm{m}$ resolution USGS LULC data. The following discussion of specific relationships in selected ecoregions is broken into three sections: those regions that are predominantly agricultural, those that are predominantly grassland, and those that are predominantly forested or have mixed LULC. A common theme linking the ecoregions is that, while NDVI/VPMs had stronger correlations to stream conditions, understanding the LULC composition within the watersheds was important in understanding the relationships of the VPMs to stream condition.

\section{Agricultural regions}

In the Western Plains and Tablelands, there was a strong negative correlation ( $r=-0.74$, Fig. 4a) between total phosphorus (TP) levels and both mean onset date and NDVI at period 8 (mid-April; Table 5). Both the NDVI and VPMs in this ecoregion (Table 7) were related to the percentage of agriculture in the watersheds and performed as well as the proportion of agriculture or the $U$ index in explaining variation in TP levels. In this case, knowledge of the general LULC and primary regional crop type(s) was helpful in interpreting the relationships. For example, the onset date in watersheds within these ecoregions is related to the dominance of winter wheat. Winter wheat begins to "green up" in late February/early March after winter 
a) Western Plains and Tablelands

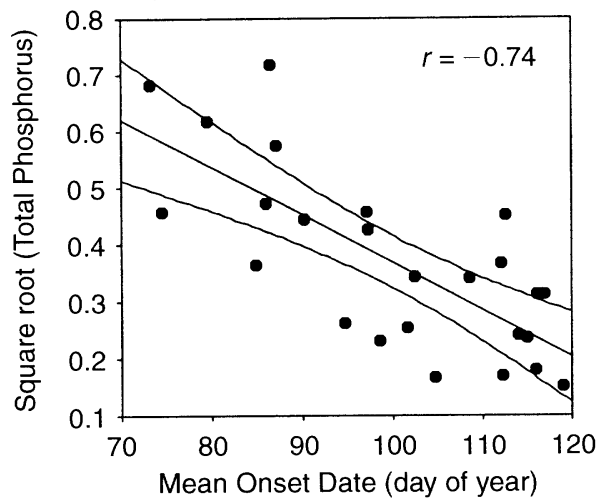

c) Western Corn Belt Plains

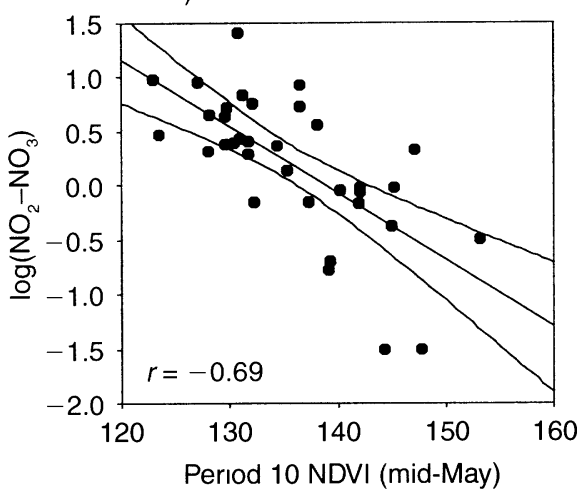

e) Central Irregular Plaıns $>260 \mathrm{~km}^{2}$

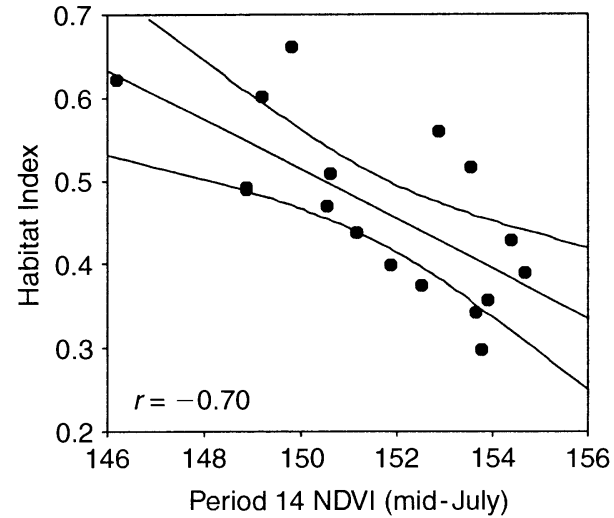

b) Western Corn Belt Plaıns $>25 \mathrm{~km}^{2}$

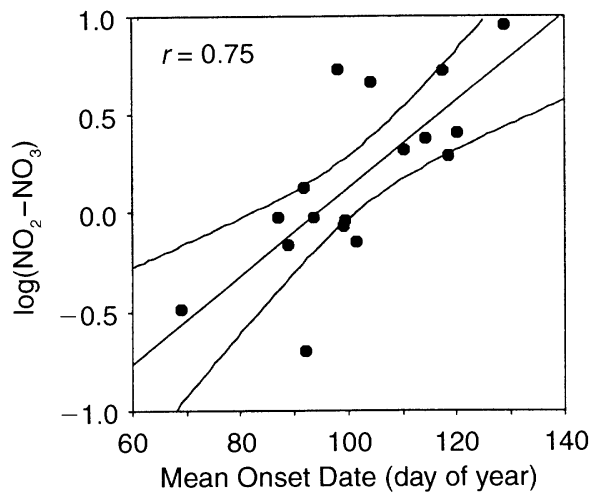

d) Central Irregular Plaıns $>260 \mathrm{~km}^{2}$

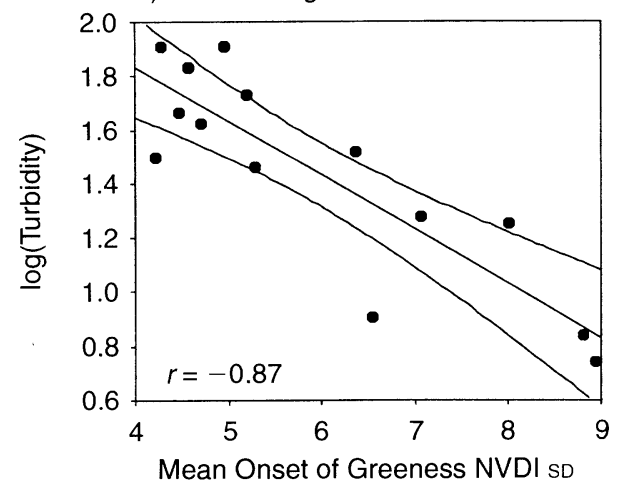

f) Central Great Plaıns $>260 \mathrm{~km}^{2}$

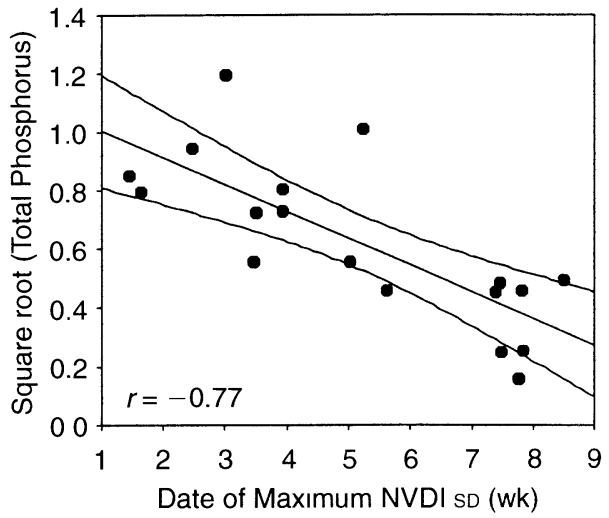

FIG. 4. Scatterplots of correlations between selected water quality or stream condition parameters and NDVI or vegetation phenological metrics. Total phosphorus and $\mathrm{NO}_{2}-\mathrm{NO}_{3}$ were originally measured in $\mathrm{mg} / \mathrm{L}$; turbidity in NTUs. Pearson correlation coefficients are shown and are significant at $\alpha=0.05 ; 95 \%$ confidence intervals are shown around the regression line. In panel (e), higher Habitat Index values indicate better conditions.

dormancy, which is much earlier than late-season crops such as corn or soybeans, and also earlier than natural grasslands (Loveland et al. 1995). Therefore, for watersheds in this region having greater amounts of agriculture, the mean onset date will usually be shifted earlier relative to watersheds having more grassland or forest.

For watersheds in the Western Corn Belt Plains, there were strong correlations between the NDVI/VPMs and $\mathrm{NO}_{2}-\mathrm{NO}_{3}$ levels (Fig. $4 \mathrm{~b}$ and c). These relationships likely result from the predominance of corn agriculture in this ecoregion. Significantly more nitrogen-based fertilizer is typically applied to corn compared to other crops in the study area ( $\mathrm{R}$. Lamond, personal communication). The typical onset of greenness in eastern Kansas occurs in late May/early June, which explains 
a) Flint Hills

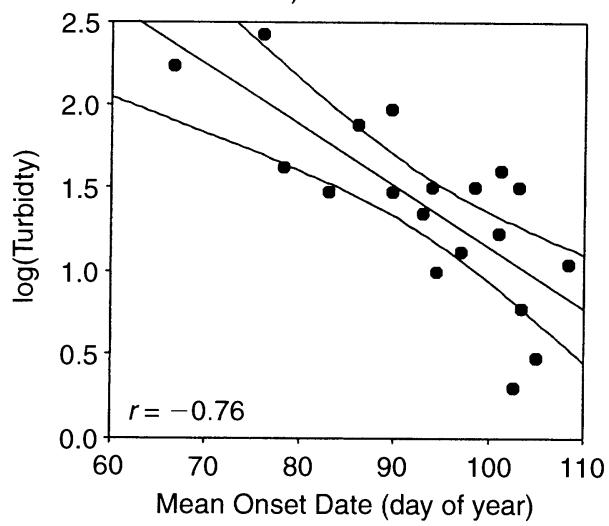

c) Ozark Highlands $<50 \mathrm{~km}^{2}$

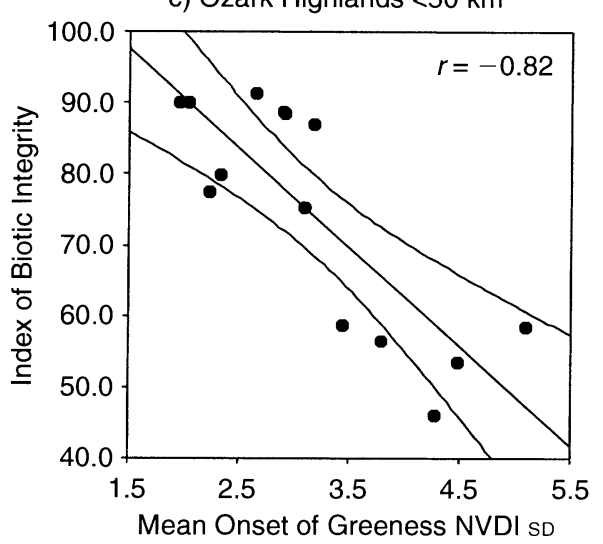

e) Mississippi River Lowlands

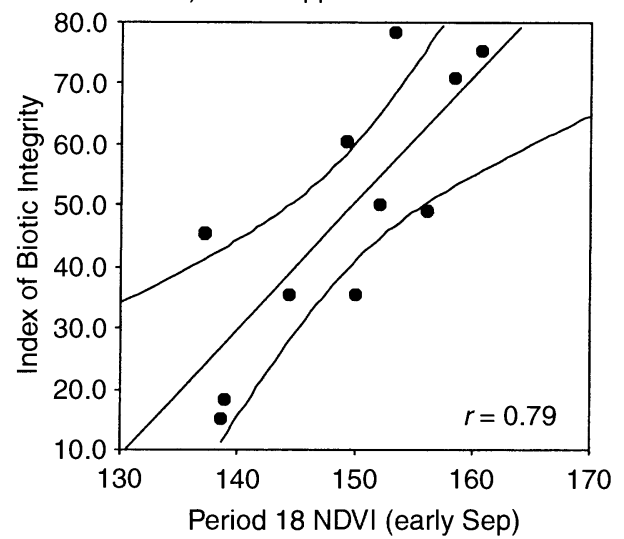

b) Sand Hills

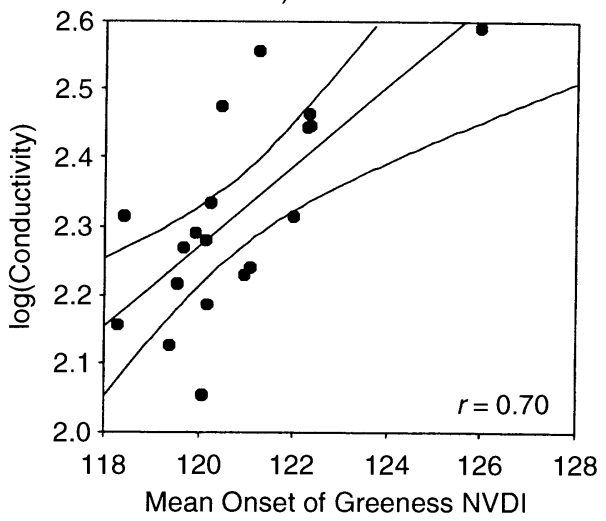

d) Ozark Hıghlands $>260 \mathrm{~km}^{2}$

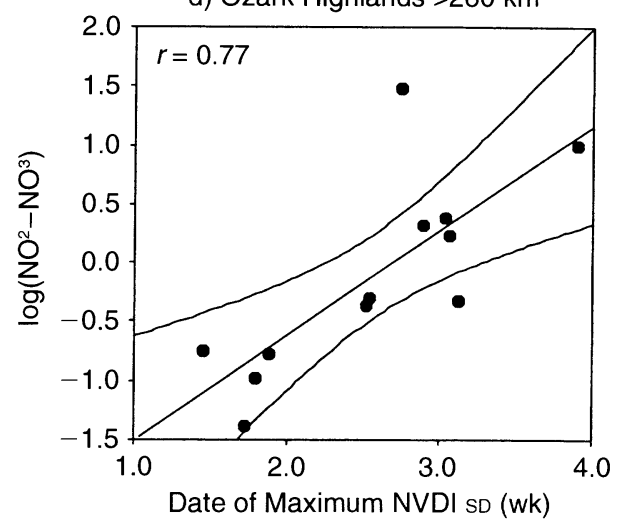

FIG. 5. Scatterplots of correlations between selected water quality or stream condition parameters and NDVI or vegetation phenological metrics. Turbidity was originally measured in $\mathrm{NTUs}, \mathrm{NO}_{2}-\mathrm{NO}_{3}$ in mg/L, and conductivity in $\mu$ mhos. Pearson correlation coefficients are shown and are significant at $\alpha=0.05 ; 95 \%$ confidence intervals are shown around the regression line. An example of the connection between LULC and the VPMs is for the Flint Hills, where a later mean onset date is associated with lower turbidity and a greater amount of grassland (see Table 7). In panels (c) and (e), higher IBI values indicate better conditions (IBI = index of biotic integrity).

why, for this ecoregion, a later onset date is associated with higher $\mathrm{NO}_{2}-\mathrm{NO}_{3}$ levels (Fig. 4b). Deciduous forest and grasslands have an earlier onset date than corn. This example underscores the importance of interpreting these relationships within the context of regional crop types. The situation in the Western Corn Belt contrasts with that in the Western Plains and Tablelands, where an earlier onset of greenness is associated with greater wheat agriculture and higher TP levels. Phosphorus levels may not be as high in the Western Corn 
TABLE 7. Correlations $(\geq 0.4)$ between selected NDVI or VPMs and LULC from $200 \mathrm{~m}$ USGS LUDA data.

\begin{tabular}{|c|c|c|c|c|c|}
\hline Ecoregion & $\begin{array}{l}\text { Percentage } \\
\text { agricul- } \\
\text { tural }\end{array}$ & $\begin{array}{l}\text { Percentage } \\
\text { forest }\end{array}$ & $\begin{array}{l}\text { Percentage } \\
\text { grassland }\end{array}$ & $\begin{array}{l}\text { Percentage } \\
\text { urban }\end{array}$ & $U$ index \\
\hline \multicolumn{6}{|c|}{ Western plains and tablelands } \\
\hline Mean onset date & -0.74 & & 0.43 & & -0.76 \\
\hline Onset NDVI SD & 0.38 & & & & \\
\hline Date of max. NDVI SD & 0.84 & & & & \\
\hline P8 NDVI & 0.67 & & -0.60 & & 0.70 \\
\hline P13 NDVI & -0.71 & & & & \\
\hline Mean date of max. NDVI & -0.58 & & & & -0.57 \\
\hline \multicolumn{6}{|l|}{ Flint Hills } \\
\hline Mean onset date & & & 0.46 & & \\
\hline P18 NDVI & & -0.54 & & & \\
\hline P8 NDVI & 0.52 & & -0.57 & & 0.52 \\
\hline \multicolumn{6}{|l|}{ Sand Hills } \\
\hline Mean onset NDVI & 0.65 & & -0.85 & & \\
\hline P14 NDVI & 0.60 & & -0.70 & & \\
\hline P11 NDVI & 0.69 & & -0.49 & & \\
\hline \multicolumn{6}{|c|}{ Western corn belt $>10 \mathrm{mi}^{2}\left(25 \mathrm{~km}^{2}\right)$} \\
\hline Mean growth rate & 0.43 & & & & \\
\hline P18 NDVI & & & -0.47 & & \\
\hline \multicolumn{6}{|c|}{ Central irregular plains $>100 \mathrm{mi}^{2}\left(260 \mathrm{~km}^{2}\right)$} \\
\hline P20 NDVI & & & 0.44 & & \\
\hline \multicolumn{6}{|c|}{ Ozark highland $<20 \mathrm{mi}^{2}\left(50 \mathrm{~km}^{2}\right)$} \\
\hline Mean onset NDVI & -0.58 & 0.60 & & & -0.60 \\
\hline Mean onset date & 0.68 & 0.70 & & & -0.70 \\
\hline \multicolumn{6}{|l|}{ Ozarks $>100 \mathrm{mi}^{2}\left(260 \mathrm{~km}^{2}\right)$} \\
\hline Date of max. NDVI SD & 0.75 & -0.75 & & 0.80 & 0.75 \\
\hline \multicolumn{6}{|c|}{ Central Great Plains $<30 \mathrm{mi}^{2}\left(75 \mathrm{~km}^{2}\right)$} \\
\hline Date of max. NDVI SD & -0.57 & & 0.57 & & -0.57 \\
\hline \multicolumn{6}{|c|}{ Central Great Plains $>100 \mathrm{mi}^{2}\left(260 \mathrm{~km}^{2}\right)$} \\
\hline P11 NDVI & -0.51 & & 0.52 & -0.52 & -0.54 \\
\hline \multicolumn{6}{|l|}{ Mississippi River lowlands } \\
\hline P18 NDVI & & 0.56 & & -0.68 & \\
\hline P16 NDVI & & 0.57 & & -0.88 & \\
\hline Date of max. NDVI & 0.61 & & & -0.69 & \\
\hline
\end{tabular}

Notes: These relationships often helped explain the correlations between the NDVI and VPMs with the stream data. All correlations were significant at $\alpha=0.05$. All variables that were significantly correlated to an LULC class are shown. If a variable does not appear, it was not significantly correlated to any of the LULC classes.

Belt, as the increased nitrogen in the receiving waters may increase precipitation of $\mathrm{P}$ and uptake by aquatic plants.

Because corn in the Western Corn Belt Plains does not "green up" until late May/early June, NDVI from period 10 (mid to late May) is negatively correlated with $\mathrm{NO}_{2}-\mathrm{NO}_{3}$ levels (Fig. 4c). At this time of year, corn is just emerging, or other fields are likely to be in stubble or be bare ground. These ground conditions produce lower NDVI values than green vegetation. NDVI values for period 16 (early to mid-August), however, are positively correlated with $\mathrm{NO}_{2}-\mathrm{NO}_{3}$ (Table 5), because the corn has matured and is near peak greenness at this time. Notice, however, that NDVI in this ecoregion is not correlated with the percentage of land in agriculture (Table 7), although period 18 NDVI is negatively correlated with the percentage of grassland.
The lack of correlation with the percentage of land in agriculture probably results from the lack of much variation in the percentage of land in agriculture among the watersheds when compared to mean onset date (Table 8 ). Thus, although the NDVI/VPMs in some instances are associated with LULC (e.g., Western High Plains and Western Corn Belt Plains for conductivity, TP, and turbidity), they apparently provide increased information content as well, because they are more highly correlated with certain stream condition parameters.

For large watersheds in the Central Irregular Plains $\left(>260 \mathrm{~km}^{2}\right)$, an area also having significant corn and soybean agriculture, period 8 NDVI (late April) values were strongly negatively correlated with turbidity (Table 6), because at this time of the year most fields have just been planted, or still have stubble. The standard 


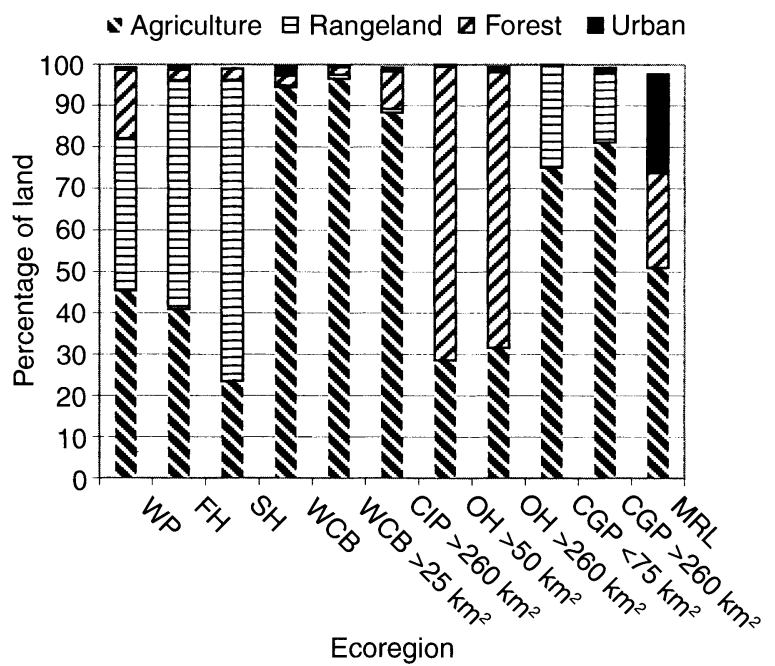

FIG. 6. Bar graph of mean LULC proportions within watersheds of each of the selected ecoregions or size stratifications within an ecoregion. Abbreviations are: WP, Western High Plains and Tablelands; FH, Flint Hills; SH, Sand Hills; WCB, Western Corn Belt Plains; CIP, Central Irregular Plains; $\mathrm{OH}$, Ozark Highlands; CGP, Central Great Planns; MRL, Mississippı River Lowlands. The proportions do not add up to exactly $100 \%$ in some cases because water, wetland, and barren LULC types are not included.

deviation of the NDVI value at the onset of greenness was strongly negatively correlated with turbidity levels in streams (Fig. 4d). The reason for this is that the landscape in these watersheds is overwhelmingly agricultural, having a mean percentage of land in agriculture of $88 \pm 6.2 \%$ (Fig. 6). Because these watersheds have relatively little urban, grassland, or other LULC types, any deviations from agricultural land use in this region likely result from the presence of forest. Similarly, NDVI values at the onset of greenness for forest are different from those for wheat, corn, or sorghum, and therefore increase variability. Because most upland areas are cultivated, any forest is likely to be riparian forest, which acts to reduce turbidity levels and sedimentation levels in streams (Schlosser and Karr 1981, Carpenter et al. 1998). Period 14 NDVI (mid-July) was negatively correlated with the HI (Fig. 4e). Although not correlated with the percentage of land in agriculture or the percentage of grassland, it is likely that there is a linkage. Higher mid-July NDVI values reflect greater intensity of late-season crops like corn or soybeans, and lower mid-July NDVI values may represent less intensive agriculture and possibly more intact riparian conditions that lead to increased habitat quality. In larger watersheds $\left(>260 \mathrm{~km}^{2}\right)$ of the Central Great Plains, less variation in the date of maximum NDVI was correlated with higher TP levels (Fig. 4f). This relationship exists probably because the dominant LULC type is agriculture (mean percentage of land in agriculture $=81 \pm 11 \%$ ). Any variation in these relatively homogeneous agricultural watersheds would likely stem from the presence of grassland, which would tend to be associated with relatively better stream conditions.

\section{Grassland regions}

In the Flint Hills (Fig. 5a), the mean onset date was negatively correlated with turbidity levels. Examining the relationship of mean onset date to LULC in the Flint Hills (Table 7) shows that an earlier date of onset of greenness indicates less grassland, which helps explain the VPMs' negative relationship with turbidity. Less grassland likely indicates a more human-impacted system; greater amounts of agriculture were also associated with an earlier onset date $(r=-0.40, \alpha=$ 0.10 ). In the Sand Hills, conductivity increases with a higher NDVI value at the onset of greenness (Fig. 5b). Table 7 shows that this value is positively related to the proportion of agriculture and negatively related to the proportion of grassland. Higher conductivity levels are typically associated with increased chemical content in the stream, which is typical of increased agricultural activities.

\section{Forested and mixed LULC regions}

In smaller watersheds of the Ozark Highlands $(<50$ $\mathrm{km}^{2}$; Fig. 5c), there was a strong negative correlation $(r=-0.82)$ between standard deviation of NDVI values at the onset of greenness and the IBI. Most watersheds in the Ozark Highlands are predominantly forested (mean percentage of land in forest $=70 \%$; Fig 6). Clearing of the land for any purpose (e.g., urban, agriculture, or timber harvesting) would create variation in NDVI values at the onset of greenness, which logically may reflect stream conditions that are not conducive to the presence of environmentally sensitive fish species and in turn would likely decrease IBI scores. Larger watersheds in the Ozark Highlands $\left(>260 \mathrm{~km}^{2}\right.$; Fig. 5d) contrasted with watersheds of the Central Great Plains (Fig. 4f). In the Ozark Highlands, variation in the date of maximum NDVI was positively correlated with higher nutrient levels, in this case, $\mathrm{NO}_{2}-\mathrm{NO}_{3}$ levels (Fig. 5d). The standard deviation of the date of

TABLE 8. Descriptive statistics for the percentage of land in agriculture and mean date of onset of greenness in the Western corn belt plains $\left(>25 \mathrm{~km}^{2}\right)$.

\begin{tabular}{lccccc}
\hline \hline \multicolumn{1}{c}{ Parameter } & Minimum & Maximum & Mean & SE & CV \\
\hline Percentage agriculture & 86.3 & 100 & 96.5 & 1.04 & 4.5 \\
Mean onset date (day of year) & 69 & 128.8 & 102 & 3.64 & 14.7 \\
\hline
\end{tabular}

Note: $n=17$. 
maximum NDVI for these watersheds was positively correlated with the percentage of land in agriculture and the percentage of urban land, and negatively correlated with the percentage of forest cover (Table 7).

The last example comes from the Mississippi River Lowlands, where strong relationships occurred between standard deviation of the date of onset of NDVI and conductivity (Table 5), and period-18 NDVI (early September) and both IBI (Fig. 5e) and turbidity. The ecoregion's LULC again helps explain this relationship. NDVI at period 18 (early September) is positively correlated to the percentage of land in forest and negatively related to the percentage of urban land (Table 7). More-urbanized and less-forested watersheds are typically more turbid relative to watersheds with other LULC types. NDVI at onset of greenness was negatively correlated with the percentage of urban land and phosphorus (Table 7). Therefore, as onset NDVI decreases, there is both more urban land and higher total phosphorus levels. Urban lands typically provide a large phosphorus source to streams flowing through them and also increase conductivity through erosion and road salts (Carpenter et al. 1998). Moving away from urban lands thus helps explain the increase in the IBI scores which indicates better conditions.

\section{NDVI vs. LULC in water quality studies}

The reason NDVI, and the derivative VPMs, may have certain advantages over simple land cover proportions is that it is a biophysical integrator of conditions throughout the watershed. Mean NDVI takes into account multiple LULC types. For example, in a predominantly forested environment, mean NDVI values capture not only the effect of forest, but also of urban or agricultural land, and might logically be more correlated with environmental conditions than any one of them would be singly. Classification of spectral reflectance values into land cover inherently involves a loss of information. NDVI values, meanwhile, reflect the condition of vegetation at various phenological development states, including moisture status or increased greenness in agricultural watersheds, perhaps reflecting increased fertilizer application. Using NDVI and derived metrics can also capture temporal changes, as opposed to static LULC maps, which do not capture within-class variation and which typically are not updated annually. Moreover, because NDVI values are interval data as opposed to the nominal categories of LULC, it is possible to calculate a standard deviation for NDVI in a watershed, which can also estimate to a certain extent the regional mix of crop or land cover types.

Another approach to studying the physical link among land cover, NDVI, plant physiology, and water quality is to temporally analyze the relationships of a controlled set of watersheds. Although affected by weather conditions and other factors, increased greenness (NDVI) is linked to physiological activity of plants. Box et al. (1989) found global AVHRR patterns closely associated with primary production and actual evapotranspiration. Growing vegetation acts to sequester chemicals and impede sediment transport. In an agricultural area, this may be associated with water uptake and increased uptake of nutrients such as nitrogen and phosphorus, resulting perhaps in less of these chemicals in receiving waters. Usually, chemical and fertilizer applications take place when the plants are still young and bare ground is abundant, resulting in possible leaching of chemicals if they are overapplied, or in increased vulnerability to erosion. More research is needed to determine how these opposing forces counteract each other.

\section{Study limitations}

The above examples illustrate the importance of knowing about the general levels of LULC proportions and crop types in a region as a key to data interpretation. Interpreting the variability in VPM values, of course, will depend on the current mix of LULC types. For example, if a watershed is mostly forested, then variation in NDVI or VPM values might indicate more degraded stream conditions. If the percentage of land in agriculture or urban land surpasses $50 \%$, variation of the VPMs might be, in contrast, indicative of improved stream conditions.

Human errors introduced in this study include the error in watershed boundary definition, error in the positional accuracy of the sampling point, and general errors in digitizing. Any small variation in the watershed shape or sampling-point position, for small watersheds in particular, could result in a large percentage error in land cover proportions or mean VPM values. In some cases, the year of water sampling did not match the year of NDVI data acquisition. In general, instances of lower $r$ values show that factors other than LULC affect water quality. These factors include geology, slope, soils, and point sources of pollution. Multiple comparisons were made in this study, and although we did not adjust the alpha level, the consistency of the NDVI/VPMs significance across different ecoregions let us feel comfortable that these significant correlations were not spurious. Future work incorporating multivariate analyses may prove useful in further addressing this issue.

Some landscape changes have occurred since the time of the USGS LULC data that may have added to the error component found in our relationships. There has been an increase in Conservation Reserve Program lands, mainly in the central and western part of the study area. The amount of land conversion decreases as one moves east, where most of our watersheds occur. Since our stream site selection was based on a probability sample of streams, there are fewer perennial streams in these western areas and thus fewer watersheds from the west that were studied. Although increased urbanization has occurred around the metro- 
politan areas, an examination of our watersheds shows that few were located in the dynamic urban-rural fringe areas of these cities. Finally, although we are not at the point of conclusively defining the mechanisms between NDVI/VPMs and water quality, we believe the words of Flather and Sauer (1996) apply to the descriptive nature of studies such as ours, in which we have reported patterns of associations. Although they noted the danger of inferring causation from correlation, they stated that this should not preclude macroecological investigations. This type of data analysis serves an important heuristic function, can lead to insights into the factors affecting the relationships of interest, and can provide a context for interpreting and guiding future local studies (Flather and Sauer 1996).

\section{Significance and implications}

Results presented in this study concur with those of Whistler (1996), whose research on watersheds in northeastern Kansas showed that correlations between NDVI and water quality measurements were stronger than those between LULC proportions and water quality. In most cases, correlations in Whistler's (1996) study were stronger than those found in this study. The reasons that are likely to account for this difference include Whistler's (1996) selection of watersheds, which was based on criteria focusing on the effects of LULC while controlling for other environmental factors. Also, his study area was much smaller (thereby reducing variation in other environmental factors), he used finer resolution $(80 \mathrm{~m})$ NDVI data, and he performed correlations in all four seasons, wherein the season in which water quality samples were collected matched the season of the NDVI data.

Spring correlations were highest for nitrogen in the Western Corn Belt Plains in Whistler's (1996) study. In this research as well, early growing season NDVI (early May to early June) or the mean date of onset of greenness was most highly correlated to water quality samples, some of which were collected later in the summer. An important potential benefit from NDVI or VPMs revealed in this study is that, because early growing season NDVI values were most often correlated with stream parameters, the potential exists for estimating summer water quality conditions with springtime AVHRR NDVI data. Although examining individual watersheds on a temporal basis is needed to confirm this potential, the temporal relationship held for both corn and wheat growing areas in this study. In the winter wheat belt, increased greenness was associated with greater agriculture and poorer summer water quality conditions, and in the corn belt, lower NDVI in late spring (to late June) was indicative of greater bare ground and more agriculture and poorer water conditions as well. Thus, NDVI or VPMs may serve as an early warning signals of stress (Munn 1988, Kelly and Harwell 1990) to aquatic systems.

This research also supports the hypotheses of Jones et al. (1996, 2000), who postulated that NDVI has the potential to characterize watershed conditions, and Jones et al. (1997), who found that change in NDVI values over a 15-yr period in the U.S. mid-Atlantic states was useful in assessing the relative vulnerability of watersheds to conditions that impact stream water quality (e.g., urbanization and construction of new roads and reservoirs). Because NDVI performed better than LULC proportions in this study, the implications of this research support adding NDVI and VPMs to the list of landscape indicators used for regional and national level monitoring of watersheds.

Furthermore, Jones et al. (1997) generalized that, at its simplest, watersheds covered by forests in the midAtlantic region are likely to be in better condition than watersheds with high percentages of intensive land uses. In the U.S. Central Plains, outside of heavily forested southern Missouri, watersheds covered by more grassland are likely to be in better condition than those covered by agriculture. Grasslands have different phenology than most crops, therefore the date of onset of greenness or date of maximum NDVI should be useful indicators of watershed condition. These metrics are especially applicable in the central Plains, where it would be useful to assess the water quality benefits of the U.S. Department of Agriculture's Conservation Reserve Program, which promotes the return of cultivated land to native grasses.

This research is significant because broad-scale screening indicators are needed to monitor the condition of the natural resources (Messer et al. 1991, Griffith 1998, Boulton 1999). Currently, about $80 \%$ of freshwater stream miles in the U.S. are not assessed or monitored (General Accounting Office [GAO] 2000). Many countries, including the U.S., are developing national-scale monitoring programs and require indicators as surrogates of ecological condition (Bernes et al. 1986, Hirvonen 1992, Stevens 1994). In particular, agroecosystems need to be assessed for their sustainability and impact on the natural components (such as streams) of the system (LeFroy and Hobbs 1992, Waltner-Toews 1995).

To our knowledge, this research is the first demonstration of empirical NDVI-stream water-quality relationships on a regional, multistate scale. Other regional studies have either focused on LULC only (Herlihy et al. 1998), or have used NDVI to characterize watershed vulnerability to water quality impacts without testing any empirical relationships (Jones et al. 1996). The findings from the current study showed the potential for satellite-derived NDVI and VPMs to supplement ground-based investigation and to meet the need for more efficient, more cost-effective indicators of ecological condition (Kelly and Harwell 1990, Fairweather 1999). NDVI or VPMs have the characteristics needed for successful indicators: sensitivity to change across space and to stresses, integrative ability, and easily collected and used (Kelly and Harwell 1990, 
Bruns et al. 1992). Thus, NDVI could be added to the suite of indicators needed to assess water resources (Jones et al. 2000).

Another significant aspect of this work is that it revealed the ability of the NDVI or VPMs to distinguish water quality conditions in the central Plains. McDaniel et al. (1987) found it difficult to analyze spatial patterns of water quality in Kansas because of a lack of diverse water quality conditions. Results found here showed that NDVI or VPMs provided additional biological information (e.g., production, biomass, timing), and were able to show distinct relationships with a gradient of water quality conditions across ecoregions in the U.S. Central Plains. More research on NDVI data from new, finer-resolution sensors $(250 \mathrm{~m}$ and $500 \mathrm{~m})$ such as MODIS, which has only slightly less temporal resolution than AVHRR, would be useful to investigate whether these data might perform better than those from the AVHRR.

\section{Conclusions}

Statistically significant relationships were found between selected NDVI values and vegetation phenological metrics, and water quality parameters or indices of stream/fish community condition. These relationships can be examined outside the study area because of the physical linkages among plant physiology, land cover, and NDVI/VPMS, which in turn impact water quality (e.g., nutrient uptake in forested watersheds during different seasons). The VPMs or NDVI were more highly correlated to water quality than simple land cover proportions in most cases. General knowledge about the dominance of LULC within the watersheds as well as regional crop types, however, was important to interpreting relationships of the VPMs and NDVI to the stream condition parameters. Although more recent land cover data are optimal because of LULC changes, the $200 \mathrm{~m}$ USGS data from the late 1970 s proved adequate as a reference source. Given that other important factors also determine water quality and stream condition, the strength of correlation $\left(r^{2}\right.$ from 0.47 to 0.76 ) described here is interesting. Because these watersheds were chosen using random sampling, these contributing factors were not controlled for. Still, these results demonstrate that by using this sample design, the relationships between the NDVI or VPMs and stream conditions can be discerned.

These results warrant further investigation of the use of NDVI and VPMs to serve as broad-scale ecological indicators and screening tools for watershed monitoring and assessment. In future studies, it may be helpful to choose watersheds in a manner controlling for various environmental factors (e.g., size, LULC proportions, point pollution sources, etc.) and then observe temporal variation of these metrics as opposed to geographic variation. Of note is that early season NDVI was most often correlated to the stream parameters collected from late May through September. More research is needed to determine whether this temporal relationship can be used in a predictive fashion. The issue of whether or not NDVI/VPMs are "better" than LULC in examining LULC/water quality relationships is a future research topic. Even if one could obtain detailed, accurate maps of crop types, producing these on a yearly basis for large areas is not feasible. Using NDVI and VPMs obviates the costly and time-consuming step of processing satellite imagery into land cover on an annual basis. The AVHRR and NDVI thus can serve as yearly screening tools for large areas to determine watersheds at risk to degradation due to changing crop acreages. Results found in this study demonstrate the utility of NDVI and VPMs, in addition to LULC, as broad-scale indicators of environmental condition.

\section{ACKNOWLEDGMENTS}

The lead author performed this work while a graduate research assistant at the Kansas Applied Remote Sensing Program and a graduate student in the Department of Geography at the University of Kansas. The authors thank two anonymous reviewers for their constructive critiques, and the following for their reviews and guidance: Jerry DeNoyelles, Steve Egbert, and Don Huggins of the Kansas Biological Survey and Kansas Applied Remote Sensıng Program. Any remaining errors are the sole responsibility of the authors, however. This study was performed in cooperation with the U.S. Environmental Protection Agency Region VII, Kansas City, Kansas, USA; Lyle Cowles, Project Manager.

\section{Literature Cited}

Allan, J., D. Erickson, and J. Fay. 1997. The influence of catchment land use on stream integrity across multiple spatial scales. Freshwater Biology 37:149-161.

Basnyat, P., L. Teeter, K. Flynn, and B. Lockaby. 1999. Relationshıps between landscape characteristics and nonpoint source pollution inputs to coastal estuaries. Environmental Management 23(4):539-549.

Bernes, C., B. Glege, K. Johannsson, and J. Larson. 1986. Design of an integrated monitoring programme in Sweden. Environmental Monitoring and Assessment 6:113-126.

Bolstad, P., and W. Swank. 1997. Cumulative impacts of land use on water quality in a southern Appalachian watershed. Journal of the American Water Resources Association 33(3):519-553.

Boulton, A. 1999. An overview of river health assessment: philosophies, practice, problems and prognosis. Freshwater Biology 1999 41:469-479.

Box, E., B. Holben, and V. Kalb. 1989. Accuracy of the AVHRR vegetation index as a predictor of biomass, primary productivity and net $\mathrm{CO}_{2}$ flux. Vegetatio 80:71-79.

Bruns, D., G. Wiersma, and G. Minshall. 1992. Evaluation of community and ecosystem monitoring parameters at a high-elevation, Rocky Mountain site. Environmental Toxicology and Chemistry 11:459-472.

Bryce, S., J. Omernik, and D. Larson. 1999. Ecoregions: a geographic framework to guıde risk characterızation and ecosystem management. Environmental Practıce 1(3): 142155.

Carpenter, S., N. Caraco, D. Correll, R. Howarth, A. Sharpley, and V. Smith. 1998. Nonpoint pollution of surface waters with phosphorus and nitrogen. Ecological Applications 8: 559-568.

Chapman, S. S., J. M. Omernik, J. A. Freeouf, D. G. Huggıns, J. R. McCauley, C. C. Freeman, G. Steinauer, R. T. Angelo, and R. L. Schlepp. 2001. Ecoregions of Kansas and Nebraska. Color poster with map, descriptive text, and sum- 
mary tables; map scale 1:1950 000. U.S. Geological Survey, Reston, Virginia, USA.

Cooper, C. M. 1993. Biological effects of agriculturally derived surface water pollutants on aquatic systems-a review. Journal of Environmental Quality 22:402-408.

Cross, F. B., and J. T. Collins. 1995. Fishes in Kansas. University of Kansas Natural History Museum Public Education Series No. 14. University of Kansas, Lawrence, Kansas, USA.

Cross, F. B., R. L. Mayden, and J. D. Stewart. 1986. Fishes in the western Mississippi Basin (Missouri, Arkansas, and Red Rivers). Pages 363-412 in C. H. Hocutt and E. O. Wiley, editors. The zoogeography of North American fishes. John Wiley and Sons, New York, New York, USA.

Eberle, M. E., G. Ernsting, J. R. Tomelleri, and S. Wells. 1993. Assessment of restored streamflow on fish communities in the Arkansas River of southwestern Kansas. Transactions of the Kansas Academy of Sciences 96:114130.

Eidenshink, J. 1992. The 1990 AVHRR conterminous U.S. data set. Photogrammetric Engineering and Remote Sensing 58:809-813.

EPA (Environmental Protection Agency). 1994. Landscape monitoring and assessment research plan. EPA 620/R-94/ 009. Environmental Monitoring Systems Laboratory, Las Vegas, Nevada, USA.

EPA (Environmental Protection Agency). 1997. Quality assurance project plan for measuring the health of the fisheries in EPA Region VII. U.S. Environmental Protection Agency. Environmental Services Division, Kansas City, Kansas, USA.

Fairweather, P. 1999. State of environment indicators of river health: exploring the metaphor. Freshwater Biology 41: 211-220.

Flather, C. H., and J. R. Sauer. 1996. Using landscape ecology to test hypotheses about large-scale abundance patterns in migratory birds. Ecology 77:28-35.

GAO (General Accounting Office). 2000. Water quality: key EPA and state decisions limited by inconsistent and incomplete data. U.S. General Accounting Office. GAO/ RCED-00-54. Washington, D.C., USA.

Goodin, D., J. Mitchell, M. Knapp, and R. Bivens. 1995. Climate and weather atlas of Kansas: an introduction. Educational Series 12. Kansas Geological Survey, Lawrence, Kansas, USA.

Griffith, J. 1998. Connecting ecological monitoring and ecological indicators: a review of the literature. Journal of Environmental Systems 26:325-363.

Griffith, J., E. Martinko, and J. Whistler. 2000. Vegetation phenological metrics and their relation to water quality and biophysical condition in Central Plains streams. In Proceedings of the 2000 American Society for Photogrammetry and Remote Sensing (ASPRS) annual conference, May 23-27 [CD]. ASPRS, Washington, D.C., USA.

Hall, K., and H. Schreier. 1996. Urbanization and agricultural intensification in the lower Fraser River Valley: impacts on water use and quality. GeoJournal 40:135-146.

Harris, J., and R. Silveira. 1999. Large-scale assessments of river health using an Index of Biotic Integrity with lowdiversity fish communities. Freshwater Biology 41:235252.

Herlihy, A., J. Stoddard, and C. Johnson. 1998. The relationship between stream chemistry and watershed land cover data in the Mid-Atlantic Region. Water, Air, and Soil Pollution 105:377-386.

Hirvonen, H. 1992. The development of regional-scale ecological indicators: a Canadian approach. Pages 901-915 in D. McKenzie, D. Hyatt, and J. McDonald, editors. Ecological indicators. Elsevier, Essex, UK.

Hobbs, R. J. 1990. Remote sensing of spatial and temporal dynamics of vegetation. Pages 203-219 in R. J. Hobbs and H. A. Mooney, editors. Remote sensing of biosphere functioning. Springer-Verlag, New York, New York, USA.

Jensen, J. 1996. Introduction to digital image processing. Prentice Hall, Upper Saddle River, New Jersey, USA.

Johnson, L., and S. Gage. 1997. Landscape approaches to the analysis of aquatic ecosystems. Freshwater Biology 37: $113-132$.

Johnson, L., C. Richards, G. Host, and J. Arthur. 1997. Landscape influences on water chemistry in Midwestern stream ecosystems. Freshwater Biology 37: 193-208.

Jones, K. B., et al. 2000. Assessing landscape condition relative to water resources in the western U.S.: a strategic approach. Environmental Monitoring and Assessment 64: 227-245.

Jones, K. B., K. Riitters, J. Wickham, R. Tankersly, Jr., R. O'Neill, D. Chaloud, E. Smith, and A. Neale. 1997. An ecological assessment of the United States mid-Atlantic region: a landscape atlas. EPA/600/R-97/130. Environmental Protection Agency, Office of Research and Development, Washington, D.C., USA.

Jones, K. B., J. Walker, K. Riitters, J. Wickham, and C. Nicoll. 1996. Indicators of landscape integrity. Pages 155-168 in J. Walker and D. Reuter, editors. Indicators of catchment health. CSIRO, Melbourne, Australia.

Karr, J. 1991. Biological integrity: a long-neglected aspect of water resources management. Ecological Applications 1:66-72.

Karr, J. 1993. Defining and assessing ecological integrity: beyond water quality. Environmental Toxicology and Chemistry 12(9):1521-1532.

Karr, J., and E. Chu. 1997. Biological monitoring and assessment: usıng multımetric indexes effectively. EPA 235 R97-001. U.S. Environmental Protection Agency, Washington, D.C., USA.

Karr, J., K. Fausch, P. Angermeier, P. Yant, and I. Schlosser. 1986. Addressing biological integrity in running waters: a method and its rationale. Illinors Natural History Survey, Champargn, Illinors, USA.

Kaufmann, P., P. Levine, E. Robison, C. Seliger, and D. Peck. 1999. Quantifying physical habitat in wadeable streams. EPA 620/R-99/003. U.S. Environmental Protection Agency, Washington, D.C., USA.

Keeney, D., and T. Deluca. 1993. Des Moines River nitrate in relation to watershed agricultural practices: 1945 versus 1980s. Journal of Environmental Quality 22:267-272.

Kelly, J., and M. Harwell. 1990. Indicators of ecosystem recovery. Environmental Management 14(5):527-545.

Lauver, C., and J. Whistler. 1993. A hierarchical classification of Landsat TM imagery to identify natural grassland areas and rare species habitat. Photogrammetric Engineering and Remote Sensing 60(10):627-634.

Lefroy, T., and R. Hobbs. 1992. Ecological indicators for sustainable agriculture. Australıan Journal of Soil and Water Conservation 5(4):22-28.

Lenat, D., and J. Crawford. 1994. Effects of land use on water quality and aquatic biota of three North Carolina Piedmont streams. Hydrobiologia 294:185-199.

Loague, K. 1998. The challenge of predicting nonpoint source pollution. Environmental Science and Technology 32(5): 130A.

Loveland, T., J. Merchant, J. Brown, D. Ohlen, B. Reed, P. Olson, and J. Hutchinson. 1995. Seasonal land-cover regions of the United States. Annals of the Association of American Geographers 85(2):339-355.

Lowrance, R., R. Leonard, and J. Sheridan. 1985. Managing riparian ecosystems to control nonpoint pollution. Journal of Soil and Water Conservation 40:87-91.

Maddock, I. 1999. The importance of physical habitat as- 
sessment for assessing river health. Freshwater Biology 41(2):373-392.

Matson, P., W. Parton, A. Power, and M. Swift. 1997. Agricultural intensification and ecosystem properties. Science 277:504-509.

McDaniel, T., C. Hunsaker, and J. Beauchamp. 1987. Determining regional water quality patterns and their ecological relationships. Environmental Management 11(4):507-518.

Messer, J., R. Linthurst, and W. Overton. 1991. An EPA program for monitoring ecological status and trends. Environmental Monitoring and Assessment 17(1):67-78.

Munn, R. 1988. The design of integrated monitoring systems to provide early indications of environmental/ecological changes. Environmental Monitoring and Assessment 11: 203-217.

Omernik, J. 1976. The influence of land use on stream nutrient levels. EPA-600/3-88/037. U.S. Environmental Protection Agency, Washington, D.C., USA.

Omernik, J. 1987. Ecoregions of the conterminous United States. Annals of the Association of American Geographers 77:118-125.

Omernik, J. M. 1995. Ecoregions-a framework for environmental management. Pages 49-62 in W. Davis and T. Simon, editors. Biological assessment and criteria. Lewis, Boca Raton, Florida, USA.

O’Neill, R., C. Hunsaker, K. Jones, K. Riitters, J. Wickham, P. Schwartz, B. Jackson, and W. Baillargeon. 1997. Monitoring environmental quality at the landscape scale. BioScience 47:513-519.

Osborne, L., and M. Wiley. 1988. Empirical relationships between land use, cover and stream water quality in an agricultural watershed. Journal of Environmental Management 26:9-27.

Peterjohn, W., and D. Correl. 1984. Nutrient dynamics in an agricultural catchment: observations on the role of a riparian forest. Ecology 65:1466-1475.

Reed, B., J. Brown, D. VanderZee, T. Loveland, J. Merchant, and D. Ohlen. 1994. Measuring phenological variability from satellite imagery. Journal of Vegetation Science 5: $703-714$

Richards, C., L. Johnson, and G. Host. 1996. Landscapescale influences on stream habitats and biota. Canadian Journal of Fisheries and Aquatıc Sciences 53(Supplement 1):295-311.

Riebsame, W. 1990. The United States Great Plains. Pages 561-576 in B. Turner and W. Meyer, editors. The Earth as transformed by human action. Cambridge University Press, Cambridge, UK.

Roth, N., J. Allan, and D. Erickson. 1996. Landscape influences on stream biotic integrity assessed at multıple spatial scales. Landscape Ecology 11(3):141-156.

Roux, D., H. Van Vliet, and M. Van Veelen. 1993. Towards integrated water quality monitoring: assessment of ecosystem health. Water SA 19(4):275-279.

Schlosser, I. 1991. Stream fish ecology: a landscape perspective. BioScience 41:704-710.

Schlosser, I., and J. Karr. 1981. Water quality in agricultural catchments: impact of riparian vegetation during base flow. Water Resources Bulletin 17:233-240.

Schroeder, W. 1982. Missouri water atlas. Missouri Department of Conservation, Jefferson City, Missourı, USA.

Sharpley, A., and M. Meyer. 1994. Minimizing agricultural nonpoint-source impacts: a symposium overview. Journal of Environmental Quality 23(1):1-13.

Sidle, R., and J. Hornbeck. 1991. Cumulative effects: a broader approach to water quality research. Journal of Soil and Water Conservation 46:268-271.

Skinner, J., K. Lewis, K. Bardon, P. Tucker, J. Catt, and B. Chambers. 1997. An overview of environmental impact of agriculture in the U.K. Journal of Environmental Management 50:111-128.

Smith, O. H., G. W. Peterson, and B. A. Needelmann. 2000 Environmental indicators of agroecosystems. Advances in Agroecosystems 69:75-97.

Stevens, D. 1994. Implementation of a national environmental monitoring program. Journal of Environmental Management 42(1): 1-30.

Stevens, J. 1996. Applied multivariate statistics for the social sciences. Third edition. Lawrence Erlbaum Associates, Hillsdale, New Jersey, USA.

Townsend, C., T. Crowl, C. Arbuckle, and M. Scarsbrook. 1997. The relationship between land use and physicochemistry, food resources, and macroinvertebrate communities in tributaries of the Tareri River. New Zealand: a hierarchically scaled approach. Freshwater Biology 37: 177-192.

Townsend, C., and R. Riley. 1999. Assessment of river health: accounting for perturbation pathways in physical and ecological space. Freshwater Biology 41:393-405.

U.S. Geological Survey. 1990. Land use and land cover digital data from 1:250,000 and 1:100,000-scale maps. Data user`s guide 4. U.S. Geological Survey, Reston. Virginia, USA.

Vogelmann, J. E., S. M. Howard, L. Yang, C. R. Larson, B. Wylie, N. VanDriel. 2001. Completion of the 1990s national land cover data set for the conterminous United States from Landsat thematic mapper data and ancillary sources. Photogrammetric Engineering and Remote Sensing 67(6):650-662.

Waltner-Toews, D. 1996. Ecosystem health-a framework for implementing sustainability in agriculture. BioScience 46: 686-689.

Whistler, J. 1996. A phenological approach to land cover characterization using Landsat MSS data for analysis of nonpoint source pollution. KARS Report No. 96-1. Kansas Applied Remote Sensing Program, Unıversity of Kansas, Lawrence, Kansas, USA.

Whistler, J. L., S. L. Egbert, M. E. Jakubauskas, E. A. Martinko, D. Baumgartner, and R. Lee. 1995. The Kansas state land cover mapping project: regional scale land use/land cover mapping using Landsat thematic mapper data. Pages 773-785 in Proceedings of the American Congress on Surveying and Mapping and American Society for Photogrammetry and Remote Sensing (ACSM/ASPRS) 1995 annual convention and exposition, Charlotte, North Carolina, February 27-March 2. ACSM/ASPRS, Bethesda, Maryland, USA.

Wichert, G., and D. Rapport. 1998. Fish community structure as a measure of degradation and rehabilitation of riparian systems in an agricultural drainage basin. Environmental Management 22(3):425-443.

Wiley, M., S. Kohler, and P. Seelbach. 1997. Reconciling landscape and local views of aquatic communities: lessons from Michigan trout streams. Freshwater Biology 37:133148.

Williams, J., and D. Murfield, editors. 1977. Agricultural atlas of Nebraska. University of Nebraska Press, Lincoln, Nebraska, USA.

Zelt, R., J. Brown, and M. Kelley. 1995. Validation of national land cover characteristics data for regional water quality assessment. Geocarto International 10(4):69-80. 